\title{
Suppression of Endothelin-1-induced Mitogenic Responses of Human Aortic Smooth Muscle Cells by Interleukin-1及
}

\author{
Yasushi Fujitani, Haruaki Ninomiya, * Toshikazu Okada, Yoshihiro Urade, and Tomoh Masaki* \\ International Research Laboratories, Ciba-Geigy Japan Ltd., Takarazuka 665, Japan; and *Department of Pharmacology, \\ Faculty of Medicine, Kyoto University, Kyoto 606, Japan
}

\begin{abstract}
When applied to quiescent human aortic smooth muscle cells (AOSMC), endothelin-1 (ET-1) caused significant increases in mitogen-activated protein kinase (MAPK) activity, $\left[{ }^{3} \mathrm{H}\right]$ thymidine incorporation, and cell proliferation, confirming an activity of ET-1 as a potent mitogen on AOSMC. As an in vitro model to evaluate the significance of the mitogenic activity of ET-1 on smooth muscle cells during atherogenesis, we studied possible modulations of the responsiveness of the cells by treatment with various

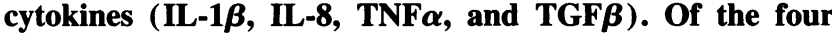
cytokines tested, we found that the treatment of the cells with IL-1 $\beta$ dramatically reduced the responsiveness of the cells to ET-1; IL-1 $\beta$ treatment at the concentration of 0.2 $\mathrm{ng} / \mathrm{ml}$ for $8 \mathrm{~h}$ completely abolished the activity of ET-1 to induce the mitogenic responses. IL-1 $\beta$ treatment caused no changes in the responses induced by EGF, basic fibroblast growth factor, or PDGF. Studies on ET-1-induced intracellular signaling events in IL-1 $\beta$-treated cells revealed that the failure of ET-1 to induce mitogenic responses was due to an increase in cAMP formation secondary to ET-1-induced activation of prostanoid metabolism. These findings on AOSMC in vitro raise the possibility that, under some inflammatory conditions in vivo, ETs may work as a negative modulator of smooth muscle cell proliferation. (J. Clin. Invest. 1995. 95:2474-2482.) Key words: endothelin • interleu-

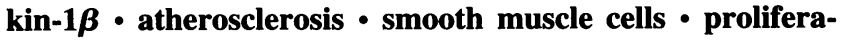
tion
\end{abstract}

Address correspondence to Tomoh Masaki M.D., Ph.D., Department of Pharmacology, Faculty of Medicine, Kyoto University, Kyoto 606, Japan. Phone: 75-753-4477; FAX: 75-753-4402. Y. Urade's present address is Department of Molecular Behavioral Biology, Osaka Bioscience Institute, Osaka 565, Japan.

Received for publication 23 December 1994 and in revised form 21 February 1995.

1. Abbreviations used in this paper: AOSMC, human aortic smooth muscle cells; bFGF, basic fibroblast growth factor; $B_{\max }$, maximum binding capacity; $\left[\mathrm{Ca}^{2+}\right]_{i}$, intracellular $\mathrm{Ca}^{2+}$ concentration; $\mathrm{CPLA}_{2}$, cytosolic phospholipase $A_{2}$; ET, endothelin; $E_{A}$, endothelin $n_{A}$ receptor; G protein, guanyl nucleotide-binding regulatory protein; HBS, Hepesbuffered saline; IBMX, 3-isobuthyl-1-methylxanthine; Iso, isoprolenaline; MAPK, mitogen-activated protein kinase; MBP, myelin basic protein; MTT, 3-(4,5-dimethylthiazol-2-yl)-2,5-diphenyltetrazolium bromide; PLA $A_{2}$; phospholipase $A_{2}$; PLC, phospholipase C; SMC, smooth muscle cells.

J. Clin. Invest.

(c) The American Society for Clinical Investigation, Inc.

0021-9738/95/06/2474/09 $\$ 2.00$

Volume 95, June 1995, 2474-2482

\section{Introduction}

The endothelin (ET) ${ }^{1}$ family of peptides includes three isoforms termed ET-1, ET-2, and ET-3 (1). Since the isolation of ET-1 as a vasoactive peptide released from endothelial cells (2), effects of ETs on vascular bed have been well characterized. It is now generally agreed that ETs induce vascular constriction through $\mathrm{ET}_{\mathrm{A}}$ subtype of receptors $\left(\mathrm{ET}_{\mathrm{A}}\right)$ on smooth muscle cells (SMC) $(3,4)$ and transient relaxation through $\mathrm{ET}_{B}$ subtype of receptors $\left(\mathrm{ET}_{\mathrm{B}}\right)$ on vascular endothelium (5) by stimulating the release of endothelium-derived relaxation factor $(6,7)$. In addition to their action on vascular tonus, numerous studies described diverse biological activities of the peptides including an action of ETs as a potent mitogen on SMC (8-10). Soon after immunoassay systems were established, clinical studies revealed elevated plasma levels of immunoreactive ET in patients with disease conditions such as atherosclerosis (11) or hyperlipoproteinemia (12) and a study on experimental animals described the effect of hypercholesterolemia (13). These studies suggested the potential significance of mitogenic actions of ETs on SMC during atherogenesis. The involvement of ETs in atherogenesis has been further suggested by studies on cultured cells demonstrating that oxidized low-density lipoproteins, which accumulate in vessel walls during atherogenesis, stimulated macrophages to secrete immunoreactive ET (14) and also endothelial cells to induce expression of mRNA for preproendothelin and release of immunoreactive ET (15).

According to the current view of atherogenesis (16), atherosclerosis is supposed to be a consequence of an excessive inflammatory-fibroproliferative response of the vascular wall to numerous different forms of stimuli resulting in an accumulation of various kinds of cells including SMC, endothelial cells, and macrophages at the lesion. These cells release various cytokines, growth factors, and vasoactive peptides to influence the phenotype and behavior of neighboring cells. In search of possible targets of therapeutic intervention to halt or reverse atherogenesis, elucidation of the complex interactions of these factors has been a subject of intensive investigation. Previous studies have shown that the transition of the phenotype of SMC from a contractile, nondividing phenotype to a synthetic, dividing phenotype is a critical event in atherogenesis and that, of the various cytokines involved in the process, IL-1, TNF, and TGF secreted by endothelial cells or macrophages play key roles in the phenotype transition (16).

Because we could confirm the activity of ET-1 as a potent mitogen on cultured SMC from human aorta (AOSMC), as an attempt to evaluate the significance of the mitogenic activities of ET-1 on SMC under inflammatory conditions during atherogenesis, this study was designed to investigate possible modulations of the ET-1-induced mitogenic responses of the cells by prior treatment with various cytokines (IL-1 $\beta, \mathrm{IL}-8, \mathrm{TNF} \alpha$, and TGF $\beta$ ). 


\section{Methods}

Materials. Synthetic human ET-1, ET-3, and angiotensin II were obtained from Peptide Institute (Osaka, Japan). BQ123 was from Peninsula Labs., Inc. (Belmont, CA). Human recombinant IL-1 $\beta$, IL-8, TNF $\alpha$, TGF $\beta$, PDGF-BB homodimer, basic fibroblast growth factor (bFGF), and EGF were from Genzyme Corp. (Cambridge, MA). DME and FCS were from GIBCO-BRL (Tokyo, Japan). [Methyl- ${ }^{3} \mathrm{H}$ ]Thymidine (3.1 TBq/mmol), [ $\left.{ }^{125} \mathrm{I}\right] \mathrm{ET}-1(74 \mathrm{TBq} / \mathrm{mmol}),\left[\gamma-{ }^{32} \mathrm{P}\right] \mathrm{ATP}$ (220 TBq/mmol), mitogen-activated protein kinase (MAPK) assay kit, and cAMP radioimmunoassay assay kit were from Amersham International (Amersham, Buckinghamshire, United Kingdom). U-73122 (1(6-[(17 $\beta$-3-methoxyestra-1,3,5(10)-trien-17-yl)amino]hexyl)-1H-pyrrole-2,5-dione) and $A B C$ immunodetection kit (Vecstain) were from Funakoshi (Tokyo, Japan). Fura-2 acetoxymethyl ester (Fura-2/AM) was from Dojin Chemicals (Tokyo, Japan). BCA microprotein assay kit was from Pierce (Rockford, IL). Cell proliferation assay kit using 3-(4,5-dimethylthiazol-2-yl)-2,5-diphenyltetrazolium bromide (MTT) was from Promega Corp. (Madison, WI). Anti-MAPK mAb was from Zymed Laboratories, Inc. (South San Francisco, CA). BQ788 was chemically synthesized in our laboratory (Ciba-Geigy Japan Ltd.). All other reagents used were of the purest grade available.

Cell culture and cytokine treatment. Primary-cultured AOSMC were obtained from KURABO (Osaka, Japan). Purity of AOSMC (>95\%) was confirmed by immunofluorescence analysis with a mAb against $\alpha$ smooth muscle actin. Cells were routinely maintained at $37^{\circ} \mathrm{C}$ in a $\mathrm{CO}_{2}$ incubator $\left(5 \% \mathrm{CO}_{2}, 95 \%\right.$ air $)$ with DME supplemented with FCS (5\%), EGF $(10 \mathrm{ng} / \mathrm{ml})$, bFGF $(2 \mathrm{ng} / \mathrm{ml})$, and dexamethasone $(0.39 \mu \mathrm{g} / \mathrm{ml})$. For treatment of the cells with cytokines, cells at $\sim 50 \%$ confluence in culture wells were made quiescent by incubation for $24 \mathrm{~h}$ with serumfree DME and then incubated for 1-24 h (usually for $8 \mathrm{~h}$ ) in serumfree DME containing an appropriate agent. All experiments were carried out with subcultured cells between the fifth and sixth passages.

Cell proliferation assay. Cells were cultured on 96-well culture plates to $\sim 50 \%$ confluence. Starved and then cytokine-treated or -untreated cells were further incubated for $48 \mathrm{~h}$ in serum-free DME containing ET-1 or other growth factors at the indicated concentrations. The number of viable cells in each well was estimated by the measurement of the rate of mitochondrial metabolism of MTT using a cell proliferation assay kit (Promega Corp.) according to the manufacturer's instructions.

$\left[{ }^{3} \mathrm{H}\right]$ Thymidine incorporation. Cells were cultured on 96-well culture plate to $\sim 50 \%$ confluence. Starved and then cytokine-treated or -untreated cells were further incubated for $24 \mathrm{~h}$ in serum-free DME containing ET-1 or other growth factors at the indicated concentrations. The cells were exposed to $\left[{ }^{3} \mathrm{H}\right]$ thymidine $(1 \mu \mathrm{Ci} / \mathrm{ml})$ during the last 4 $h$ of the incubation, washed twice with ice-cold PBS, and then incubated with $10 \%$ (vol/vol) TCA at $4^{\circ} \mathrm{C}$ for $30 \mathrm{~min}$. After removing the TCAsoluble material with ethanol, the radioactivity incorporated into the TCA-insoluble fraction was recovered in $0.5 \mathrm{~N} \mathrm{NaOH}$ and counted with a liquid scintillation counter.

MAPK assays. Cells were grown to $\sim 50 \%$ confluence in 6-well plates, deprived of serum for $24 \mathrm{~h}$, and then treated or untreated with cytokines. They were washed with PBS and then incubated in serumfree DME supplemented with $5 \mathrm{mM}$ Hepes ( $\mathrm{pH}$ 7.4). The reaction was started by addition of ET- 1 or other stimulants and was terminated by aspiration of the medium and addition of $3 \mathrm{ml}$ of ice-cold lysis buffer ( $20 \mathrm{mM}$ Tris-HCl, pH 7.4, $80 \mathrm{mM} \beta$-glycerophosphate, $2 \mathrm{mM}$ DTT, 1 mM EGTA, $1 \mathrm{mM}$ EDTA, $1 \mathrm{mM}$ sodium orthovanadate, $10 \mathrm{mM} \mathrm{NaF}$, $1 \mathrm{mM}$ PMSF, $10 \mu \mathrm{g} / \mathrm{ml}$ leupeptin, and $10 \mu \mathrm{g} / \mathrm{ml}$ aprotinin). The reaction time was $3 \mathrm{~min}$. The cells were collected by scraping the dishes with a rubber policeman, lysed by a brief sonication, and then incubated on ice for $30 \mathrm{~min}$. Insoluble material was removed by centrifugation at $10,000 \mathrm{~g}$ for $15 \mathrm{~min}$. MAPKs were partially purified from the lysate by anion exchange chromatography according to the procedures described by Koide et al. (17). In brief, the lysate was applied to a DEAEcellulose column $(0.9 \times 0.5 \mathrm{~cm})$ preequilibrated with the lysis buffer. After washing the column with $5 \mathrm{ml}$ of lysis buffer containing $0.1 \mathrm{M}$
$\mathrm{NaCl}$, MAPKs were eluted with $1.0 \mathrm{ml}$ of lysis buffer containing 0.5 $\mathrm{M} \mathrm{NaCl}$. Analysis by SDS-PAGE, Western transfer, and immunoblotting with anti-MAPK mAb (Zymed Laboratories, Inc.) verified complete recovery of MAPKs (42- and 44-kD species) in the $0.5 \mathrm{M} \mathrm{NaCl}$ eluate (data not shown). The protein concentration of the partially purified lysate was determined with BCA microprotein assay kit, and the lysate was frozen at $-80^{\circ} \mathrm{C}$ until assay. Two assay procedures were adopted in this study to measure the MAPK activity in the cell lysate. First, the kinase activity was determined using an assay kit (Amersham International) according to the manufacturer's instructions. In brief, $15 \mu \mathrm{l}$ of the cell lysate ( $2 \mu \mathrm{g}$ of protein) was added to the same volume of a reaction mixture containing $\left[\gamma_{-}{ }^{32} \mathrm{P}\right] \mathrm{ATP}(1 \mu \mathrm{Ci} /$ reaction $)$ and a synthetic peptide ( $\mathrm{NH}_{2}$-KRELVEPLTPAGEAPNQALLR-COOH) as a substrate. The reaction was let go at $30^{\circ} \mathrm{C}$ for $30 \mathrm{~min}$ and was terminated by adding a stop solution. The resulting solution was applied to a phosphocellulose membrane, and the membrane was extensively washed in $1 \%$ acetic acid and then in water. The radioactivity trapped on the membrane was measured with a liquid scintillation counter. Second, the kinase activity was measured by in-gel kinase assay using myelin basic protein (MBP) as a substrate as described by Koide et al. (17). In brief, cell lysates ( $5 \mu \mathrm{g}$ of protein) were resolved by SDS-PAGE on a $12 \%$ polyacrylamide gel containing $1 \mathrm{mg} / \mathrm{ml}$ of MBP. The gel was washed with buffer A ( $50 \mathrm{mM}$ Hepes, $\mathrm{pH} 7.4$, containing $5 \mathrm{mM}$ 2-mercaptoethanol) plus $20 \%$ of isopropanol at room temperature for $30 \mathrm{~min}$. After denaturation in buffer A containing $6 \mathrm{~N}$ guanidine- $\mathrm{HCl}$ at room temperature for $1 \mathrm{~h}$ and subsequent renaturation in buffer $A$ with $0.04 \%$ Tween 40 at $4^{\circ} \mathrm{C}$ for $16 \mathrm{~h}$, the gel was incubated at $25^{\circ} \mathrm{C}$ for $1 \mathrm{~h}$ in $10 \mathrm{ml}$ of a reaction mixture ( $25 \mathrm{mM}$ Hepes, $\mathrm{pH} 7.4,10 \mathrm{mM} \mathrm{MgCl}_{2}, 1 \mathrm{mM}$ EGTA, $5 \mathrm{mM}$ 2-mercaptoethanol, $50 \mu \mathrm{M}$ ATP, and $\left.250 \mu \mathrm{Ci}\left[\gamma-{ }^{32} \mathrm{P}\right] \mathrm{ATP}\right)$. The gel was extensively washed with $5 \%$ TCA containing $10 \mathrm{mM}$ pyrophosphate, and the bands of phosphorylated MBP were visualized by BAS2000 (Fujitsu, Tokyo, Japan).

Binding assays. Cells at $\sim 50 \%$ confluence in 24-well plates were subjected to the assays. After serum-deprivation and plus and minus cytokine treatment, the cells were washed with Hepes-buffered saline (HBS) (20 mM Hepes, pH 7.4, $140 \mathrm{mM} \mathrm{NaCl}, 4 \mathrm{mM} \mathrm{KCl}, 1 \mathrm{mM}$ $\mathrm{K}_{2} \mathrm{HPO}_{4}, 1 \mathrm{mM} \mathrm{MgCl}, 1 \mathrm{mM} \mathrm{CaCl}, 10 \mathrm{mM}$ D-glucose, and $0.1 \%$ BSA) and then incubated at $37^{\circ} \mathrm{C}$ for $1 \mathrm{~h}$ in $0.25 \mathrm{ml}$ of HBS containing [ $\left.{ }^{125} \mathrm{I}\right] \mathrm{ET}-1$ to obtain total binding. The concentrations of [ $\left.{ }^{125} \mathrm{I}\right] \mathrm{ET}-1$ used were given in legends. Nonspecific binding was determined in the presence of $100 \mathrm{nM}$ unlabeled ET-1. Specific binding was defined as total binding minus nonspecific binding. The reaction was stopped by aspiration of the reaction buffer, and the cells were washed twice with ice-cold $\mathrm{HBS}$ and solubilized in $1 \mathrm{~N} \mathrm{NaOH}$. The cell-associated radioactivity was measured in a $\gamma$-counter.

Measurement of cyclic AMP formation. Cells at $\sim 50 \%$ confluence in 24-well plates were starved and then treated or untreated with cytokines. They were washed twice with HBS and then incubated at $37^{\circ} \mathrm{C}$ for $10 \mathrm{~min}$ in $1 \mathrm{ml}$ of HBS with or without $1 \mathrm{mM} \mathrm{3-isobuthyl-1-}$ methylxanthine (IBMX). The cells were then stimulated with ET-1 or isoplenaline (Iso) at the concentrations indicated, usually for $3 \mathrm{~min}$. The reaction was stopped by addition of $10 \%$ ( $\mathrm{vol} / \mathrm{vol}$ ) TCA, and the cAMP contents in the TCA-soluble cell extracts were measured using a radioimmunoassay kit (Amersham International).

Measurement of intracellular $\mathrm{Ca}^{2+}$ concentration $\left(\left[\mathrm{Ca}^{2+}\right]_{i}\right)$. Cells in 100-mm culture dishes were dispersed by incubation in PBS containing $1 \mathrm{mM}$ EGTA and loaded with Fura-2 by incubation at $20^{\circ} \mathrm{C}$ for $35 \mathrm{~min}$ in HBS containing $4 \mu \mathrm{M}$ Fura-2/AM. The Fura-2-loaded cells were washed twice, resuspended in HBS, and kept at $20^{\circ} \mathrm{C}$. Approximately $10^{6} \mathrm{cells} / \mathrm{ml}$ were used in each set of experiments. The fluorescence of Fura-2-loaded cells was measured with a CAF-100 spectrofluorometer (Japan Spectroscopy Inc., Tokyo, Japan) with excitations at $340 \mathrm{~nm}$ and $380 \mathrm{~nm}$ and emission at $500 \mathrm{~nm}$. The $\left[\mathrm{Ca}^{2+}\right]_{\mathrm{i}}$ was calculated from the ratio of fluorescence intensities as described (18).

Statistical analysis. Results of the experiments were expressed as means \pm SEM. Student's $t$ test was used for the statistical analysis of the results. $P$ values of $<0.05$ were considered to be significant. 


\section{Results}

ET-1 failed to exert mitogenic activities on IL-1 $\beta$-treated $A O S M C$. When applied to quiescent AOSMC, ET-1 induced an increase in mitochondrial metabolism of the dye MTT (Fig. 1). Because time-course analysis on the effect of ET-1 showed that the maximum increase was obtained after $48 \mathrm{~h}$ of exposure (data not shown), the stimulation time was set to $48 \mathrm{~h}$ in the subsequent experiments. This increase in MTT metabolism was not simply due to an increased cell viability but, apparently, due to an increase in cell number as revealed by microscopic observation of the culture bed (not shown). The concentration of ET-1 to give a half maximum effect $\left(E_{50}\right)$ was within the range of 50-200 pM and the maximum effect obtained at 10 nM ET- 1 was $\sim 40 \%$ of the potency of $5 \%$ FCS. AOSMC predominantly expressed $\mathrm{ET}_{\mathrm{A}}$ subtype of ET receptors as revealed by $\left[{ }^{125} \mathrm{I}\right] \mathrm{ET}-1$ binding assays (see below) and the growth-promoting activity of ET-1 was apparently transmitted

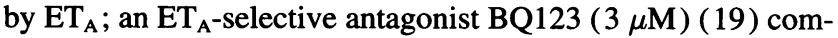
pletely suppressed the ET-1 (10 nM) -induced cell proliferation while an $\mathrm{ET}_{\mathrm{B}}$-selective antagonist $\mathrm{BQ788}(20)$ failed to inhibit the effect (data not shown). Using this cell proliferation assay, we examined whether treatment of the cells with any of the four cytokines (IL- $1 \beta, \mathrm{IL}-8, \mathrm{TNF} \alpha$, and TGF $\beta$ ) caused any changes in the cells' responsiveness to ET-1. Of the four cytokines tested, we found that the treatment of the cells with IL$1 \beta$ dramatically reduced the responsiveness of the cells to ET1 ; IL- $1 \beta$ treatment at the concentration of $0.2 \mathrm{ng} / \mathrm{ml}$ for $8 \mathrm{~h}$ completely abolished the proliferative response of the cells evoked by ET-1 (Fig. $1 a$ ). This effect of IL-1 $\beta$ was dependent both on the duration of the treatment and the dose of IL- $1 \beta$; the activity of ET-1 to induce cell proliferation was lost after $8-16 \mathrm{~h}$ of exposure to IL- $1 \beta(0.2 \mathrm{ng} / \mathrm{ml})$ and was restored after $24 \mathrm{~h}$ of exposure (Fig. $1 b$ ), and the concentration higher than $0.1 \mathrm{ng} / \mathrm{ml}$ was required to completely suppress the cells' responsiveness (Fig. $1 c$ ). Treatments of the cells with any of the other three cytokines caused no changes in the cells' responsiveness to ET-1 (Table I), suggesting the specificity of the suppressive action for IL- $1 \beta$ treatment. IL- $1 \beta$ treatment did not cause any changes either in basal or FCS-stimulated cell proliferation. Nor did it cause any changes in the cell proliferations stimulated by other growth factors including EGF, bFGF, and PDGF-BB (Table II). These results clearly showed that, when exposed to IL- $\beta$, AOSMC lost the responsiveness to the mitogenic activity of ET-1 while maintaining the responsiveness to that of other growth factors.

As an alternative parameter of the mitogenic responses of the cells, we examined ET- 1 -induced $\left[{ }^{3} \mathrm{H}\right]$ thymidine incorporation. When applied to quiescent, cytokine-untreated AOSMC for $24 \mathrm{~h}, \mathrm{ET}-1$ caused a significant increase in $\left[{ }^{3} \mathrm{H}\right]$ thymidine incorporation with $\mathrm{EC}_{50}$ values of $\sim 80 \mathrm{pM}$ and the maximum effect of approximately threefold increase above the basal values at the ET-1 concentration of $10 \mathrm{nM}$. In accordance with the results of cell proliferation assays, ET-1 failed to stimulate $\left[{ }^{3} \mathrm{H}\right]$ thymidine incorporation in $\mathrm{IL}-1 \beta$-treated $(0.2 \mathrm{ng} / \mathrm{ml}$ for $8 \mathrm{~h}$ ) cells (data not shown). Apparently, AOSMC in the G0/ G1 phases, when treated with IL- $1 \beta$, did not enter the $S$ phase in response to ET-1, suggesting an alteration(s) in the early signaling events elicited by ET- 1 .

ET-1 failed to induce MAPK activation in IL-1 $\beta$-treated cells. MAPKs are a family of serine/threonine kinases activated by numerous growth factors or hormones, and several lines of
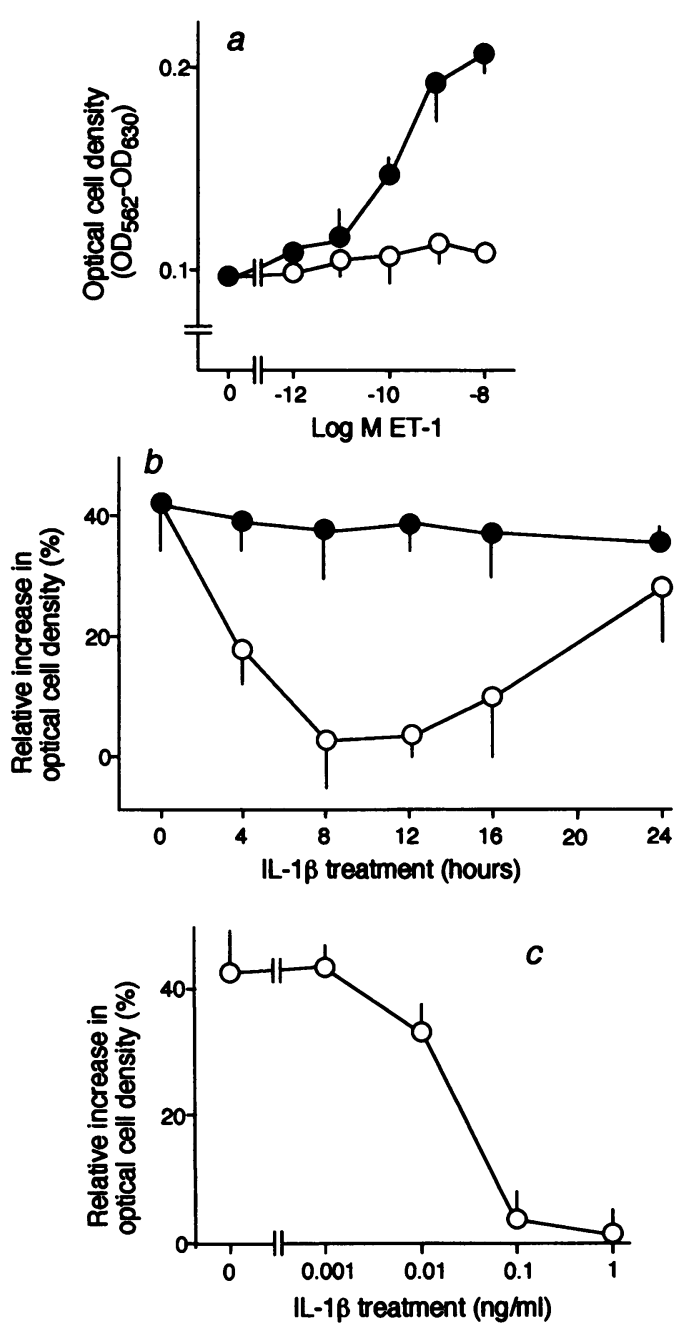

Figure 1. Effects of IL-1 $\beta$ treatment on the ET-1-induced proliferation of AOSMC. (a) Dose-response for the effect of ET-1. Cells at $~ 50 \%$ confluence in 96-well plates were starved for $24 \mathrm{~h}$ in serum-free DME and then either treated (open circles) or untreated (filled circles) with $\mathrm{IL}-1 \beta(0.2 \mathrm{ng} / \mathrm{ml})$ for $8 \mathrm{~h}$. They were washed and then stimulated with increasing concentrations of ET-1 for $48 \mathrm{~h}$. The number of viable cells in each well was estimated by MTT assay as described in Methods. Control experiments showed the linear relationship between the optical density and the cell number up to the cell density of 30,000/well $(\sim 0.3$ of $\left.\mathrm{OD}_{562}-\mathrm{OD}_{630}\right)$. Thus the ET-1-induced increase in the optical cell density $(\sim 0.1)$ of IL-1 $\beta$-untreated cells corresponds to an increase in the cell number of $\sim 10,000$ /well. Shown are the means \pm SEM of triplicate determinations obtained in a single experiment. Similar results were obtained on two other occasions. $(b)$ Dependency on the duration of IL-1 $\beta$ treatment. Starved cells were incubated in serum-free DME with (open circles) or without (filled circles) $\mathrm{IL}-1 \beta(0.2 \mathrm{ng} / \mathrm{ml}$ ) for various lengths of time. At the time indicated, the cells were washed and then further incubated for $48 \mathrm{~h}$ either in serum-free medium with or without ET-1 (10 nM) or in serum (5\% FCS)-containing medium. (c) Doseresponse for IL- $1 \beta$. Starved cells were incubated for $8 \mathrm{~h}$ in serum-free DME containing increasing concentrations of IL- $1 \beta$. The cells were then washed and either left unstimulated or stimulated by $10 \mathrm{nM}$ ET-1 or $5 \%$ FCS for $48 \mathrm{~h}$. Both in $b$ and $c$, the number of viable cells in each well was estimated by MTT assay as described in Methods. Because IL-1 $\beta$ treatment caused no changes either in basal (serum-free incubations) or in FCS-stimulated cell proliferations, the growth-promoting activity of ET-1 was expressed as the percentage of efficacy compared with that of $5 \%$ FCS. Shown are the means \pm SEM of three determinations each done in triplicate. 
Table I. Suppressive Effect on the ET-1-induced Mitogenic Response of AOSMC Was Specific for IL-1 $\beta$ Treatment

\begin{tabular}{lcc}
\hline \multirow{2}{*}{$\begin{array}{c}\text { Treatment } \\
(\mathrm{ng} / \mathrm{ml})\end{array}$} & \multicolumn{2}{c}{ Optical cell density $\left(\mathrm{OD}_{562}-\mathrm{OD}_{630}\right)$} \\
\cline { 2 - 3 } & Basal & ET-1 $(10 \mathrm{nM})$ \\
\hline None & $0.118 \pm 0.01$ & $0.211 \pm 0.01$ \\
$\mathrm{IL}-1 \beta(0.2)$ & $0.102 \pm 0.01$ & $0.118 \pm 0.01^{*}$ \\
$\mathrm{IL}-8(10)$ & $0.084 \pm 0.05$ & $0.198 \pm 0.04$ \\
TNF $\alpha(5)$ & $0.120 \pm 0.06$ & $0.200 \pm 0.05$ \\
TGF $\beta(5)$ & $0.115 \pm 0.01$ & $0.213 \pm 0.01$ \\
\hline
\end{tabular}

Starved cells in 96-well plates were untreated or treated for $8 \mathrm{~h}$ with each cytokine at the concentration indicated. They were then washed and further incubated for $48 \mathrm{~h}$ in serum-free medium with or without ET-1 $(10 \mathrm{nM})$, and the number of viable cells in each well was estimated by MTT assay as described in Methods. Shown are the means \pm SEM of triplicate determinations obtained in a single experiment. Similar results were obtained in at least one other experiment for each cytokine. * $P<0.01$, significantly different from the values of optical densities of ET-1-stimulated, nontreated cells.

evidence suggested their essential role in the cell cycle progression from G0/G1 to $S(21-23)$. When applied to quiescent AOSMC, ET-1 caused a significant increase in MAPK activity in the cytosolic cell extracts. In vitro kinase assays using a synthetic peptide as a substrate (Amersham International) gave $\mathrm{EC}_{50}$ values of $\sim 120 \mathrm{pM}$ and the maximum effect of approximately fourfold increase above the basal values (Fig. $2 a$ ). The increase in the kinase activity induced by $10 \mathrm{nM}$ ET-1 was completely inhibited by $3 \mu \mathrm{M}$ BQ123 (data not shown). Immunoblotting with anti-MAPK mAb (Zymed Laboratories, Inc.) detected two species of MAPKs (molecular sizes of 42 and 44 $\mathrm{kD}$ ) in the cell lysate (Fig. $2 b$ ). Of the two isoforms, the 42-kD MAPK was apparently the predominant form on the immunoblot, and in-gel kinase assays revealed that the ET-1induced increase in the kinase activity was largely attributed to the activation of the 42-kD MAPK. As shown in Fig. 2, ET-1 failed to induce MAPK activation in $\mathrm{IL}-1 \beta$-treated $(0.2 \mathrm{ng} / \mathrm{ml}$ for $8 \mathrm{~h}$ ) cells. Again, the suppression after IL- $1 \beta$ treatment was rather specific for ET-1; PDGF-BB $(5 \mathrm{ng} / \mathrm{ml})$ induced MAPK activation to similar degrees in $\mathrm{IL}-1 \beta$-untreated and -treated cells (3.1- and 2.9-fold over basal level, respectively).

$\mathrm{ET}_{\mathrm{A}}$ couples with $\mathrm{G} \alpha \mathrm{q}$ subfamily of $\mathrm{G} \alpha$ proteins to activate phospholipase C (PLC) (24): Although recent studies suggested the presence of multiple signaling pathways from $G$ protein-coupled receptors to MAPKs $(25,26)$, it is generally accepted that the activation of PLC by G $\alpha$, which in turn leads to $\mathrm{Ca}^{2+}$ mobilization and protein kinase $\mathrm{C}$ activation, is the main signaling pathway for $G$ protein-coupled receptors to induce MAPK activation (27). Thus we examined whether IL$1 \beta$ treatment caused any changes in $\mathrm{ET}_{\mathrm{A}}$ expression or in ET1 -induced $\left[\mathrm{Ca}^{2+}\right]_{\mathrm{i}}$ responses in AOSMC.

Upregulation of $E T_{A}$ expressed on AOSMC by $I L-1 \beta$ treatment. When quiescent cells were exposed to IL-1 $\beta(0.2 \mathrm{ng} /$ $\mathrm{ml})$, the binding of [ $\left.{ }^{125} \mathrm{I}\right] \mathrm{ET}-1(50 \mathrm{pM})$ gradually increased from the basal level $\left(1.6 \pm 0.2 \mathrm{fmol} / 10^{5}\right.$ cells, mean $\pm \mathrm{SEM}, n$ $=3)$, reached a peak at $8 \mathrm{~h}\left(2.4 \pm 0.3 \mathrm{fmol} / 10^{5}\right.$ cells $)$, and then decreased to a level of IL-1 $\beta$-untreated cells within $24 \mathrm{~h}$ (Fig. $3 a$ ). This increase in the binding was not due to a change in the binding affinities but due to an increase in the maximum
Table II. IL-1 $\beta$ Treatment Specifically Suppressed the ET-1induced Mitogenic Response of AOSMC

\begin{tabular}{lll}
\hline & \multicolumn{2}{c}{ Optical cell density $\left(\mathrm{OD}_{562}-\mathrm{OD}_{630}\right)$} \\
\cline { 2 - 3 } \multicolumn{1}{c}{ Stimulant } & Untreated & $\mathrm{IL}-1 \beta$-treated \\
\hline None & $0.118 \pm 0.01$ & $0.106 \pm 0.03$ \\
ET-1 $(10 \mathrm{nM})$ & $0.201 \pm 0.01$ & $0.098 \pm 0.01^{*}$ \\
EGF $(10 \mathrm{ng} / \mathrm{ml})$ & $0.184 \pm 0.03$ & $0.196 \pm 0.07$ \\
bFGF $(10 \mathrm{ng} / \mathrm{ml})$ & $0.217 \pm 0.04$ & $0.203 \pm 0.04$ \\
PDGF-BB $(5 \mathrm{ng} / \mathrm{ml})$ & $0.245 \pm 0.01$ & $0.243 \pm 0.01$ \\
FCS $(5 \%)$ & $0.267 \pm 0.02$ & $0.280 \pm 0.02$ \\
\hline
\end{tabular}

Starved cells in 96-well plates were either untreated or treated with $\mathrm{IL}-1 \beta(0.2 \mathrm{ng} / \mathrm{ml})$ for $8 \mathrm{~h}$. They were then washed and incubated for $48 \mathrm{~h}$ either in serum-free medium containing each growth factor at the concentration indicated or in serum (5\% FCS)-containing medium. The number of viable cells in each well was estimated by MTT assay as described in Methods. Shown are the means \pm SEM of triplicate determinations obtained in a single experiment. Similar results were obtained in at least one other experiment for each growth factor. ${ }^{*} P<0.01$, significantly different from the values of optical densities of untreated cells.

binding capacities; Scatchard analyses of saturation isotherms gave $K_{\mathrm{d}}$ values of $37 \pm 3$ and $45 \pm 5 \mathrm{pM}$ and maximum binding capacity $\left(B_{\max }\right)$ values of $35 \pm 1.5$ and $55 \pm 2.0 \times 10^{3}$ sites $/$ cell in IL- $1 \beta$-untreated and -treated $(0.2 \mathrm{ng} / \mathrm{ml}$ for $8 \mathrm{~h})$ cells, respectively (means \pm SEM, $n=3$ ) (Fig. $3 b$ ). Unlabeled ET-

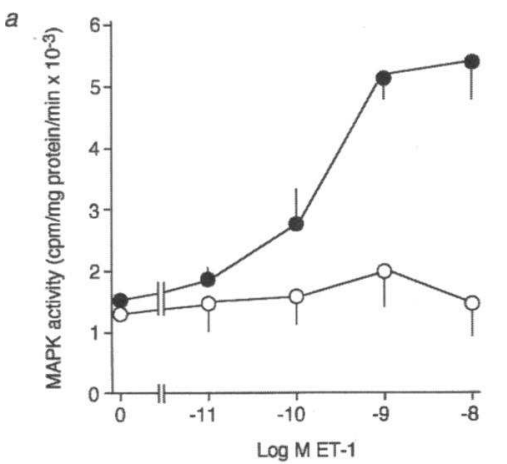

Figure 2. ET-1 failed to induce MAPK activation in IL- $1 \beta$-treated AOSMC. (a) Dose-response for the effect of ET-1. Starved cells in 6well plates were treated (open circles) or untreated (filled circles) with $\mathrm{IL}-1 \beta(0.2 \mathrm{ng} / \mathrm{ml})$ for $8 \mathrm{~h}$, washed, and then incubated in serum-free DME supplemented with $5 \mathrm{mM}$ Hepes ( $\mathrm{pH} 7.4$ ). They were then stimu-

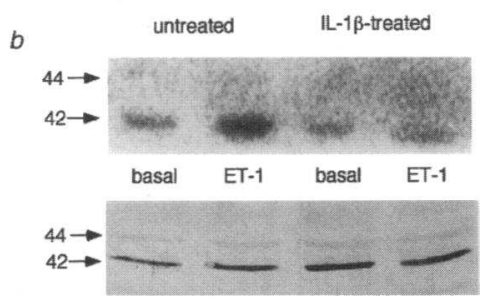
lated with increasing concentrations of ET-1 for $3 \mathrm{~min}$. The MAPK activity in the cell lysate was measured using an assay kit (Amersham International). Shown are the means \pm SEM of three determinations each done in duplicate. $(b)$

In-gel kinase assay. IL- $1 \beta$-treated $(0.2 \mathrm{ng} / \mathrm{ml}$ for $8 \mathrm{~h})$ or -untreated cells were stimulated with $10 \mathrm{nM}$ ET-1 for $3 \mathrm{~min}$. The MAPK activity in the cell lysate was measured by in-gel kinase assay as described in Methods (upper panel). The same lysates were subjected to SDSPAGE, Western transfer, and immunoblotting with anti-MAPK mAb (Zymed Laboratories, Inc.) (lower panel). The blots were developed using an $\mathrm{ABC}$ immunodetection kit (Vecstain). Arrows indicate molecular sizes (kilodaltons). 

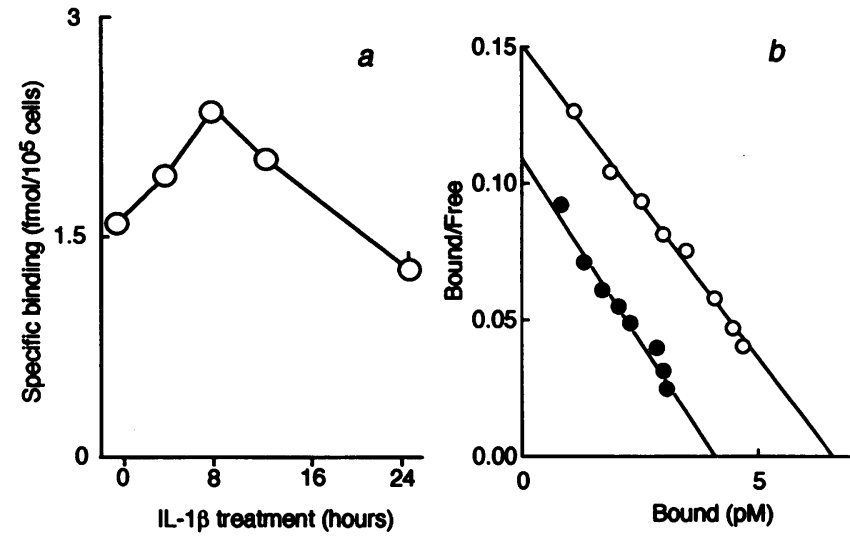

Figure 3. IL-1 $\beta$ treatment induced upregulation of $\mathrm{ET}_{\mathrm{A}}$ expressed on AOSMC. (a) Time course of upregulation of [ $\left.{ }^{125} \mathrm{I}\right] \mathrm{ET}-1$-binding sites. Starved cells in 24-well plates were treated with IL-1 $\beta(0.2 \mathrm{ng} / \mathrm{ml})$ for various time periods and then subjected to binding assays with $50 \mathrm{pM}$ [ ${ }^{125}$ I]ET-1. Values represent the means \pm SEM of three determinations each done in triplicate. $(b)$ Scatchard plots of [ $\left.{ }^{125} \mathrm{I}\right] \mathrm{ET}-1$ binding to IL$1 \beta$-treated and -untreated cells. Cells treated (open circles) or untreated (filled circles) with $\mathrm{IL}-1 \beta(0.2 \mathrm{ng} / \mathrm{ml}$ for $8 \mathrm{~h})$ were subjected to saturation isotherms with [ $\left.{ }^{125} \mathrm{I}\right] \mathrm{ET}-1(10-1000 \mathrm{pM}) . K_{\mathrm{d}}$ and $B_{\max }$ values (given in the text) were obtained by Scatchard analyses of the data. Shown are the means of triplicate determinations obtained in a single experiment. Similar results were obtained on two other occasions.

1 and BQ123 dose-dependently inhibited the binding of [ ${ }^{125}$ I]ET-1 ( $30 \mathrm{pM}$ ) to IL- $1 \beta$-treated cells with $K_{\mathrm{i}}$ values (calculated according to the equation $K_{\mathrm{i}}=\mathrm{IC}_{50} /\left(1+[\mathrm{L}] / K_{\mathrm{d}}\right)$, where $[\mathrm{L}]$ is the concentration of the radioligand used) of 70 pM and $1 \mathrm{nM}$, respectively. Unlabeled ET-3 also competed with [ ${ }^{125}$ I]ET-1, however, with a $K_{\mathrm{i}}$ value of $110 \mathrm{nM}$ which was 1,600 -fold higher than that of ET-1. Competition binding assays using IL-1 $\beta$-untreated cells gave similar $K_{\mathrm{i}}$ values for these ligands (data not shown), indicating that $\mathrm{IL}-1 \beta$ treatment resulted in upregulation of $\mathrm{ET}_{\mathrm{A}}$.

Treatment of the cells for $8 \mathrm{~h}$ with other cytokines such as IL-8 $(10 \mathrm{ng} / \mathrm{ml})$, TNF $\alpha(5 \mathrm{ng} / \mathrm{ml})$, and TGF $\beta(5 \mathrm{ng} / \mathrm{ml})$ caused no changes in the [ $\left.{ }^{125} \mathrm{I}\right] \mathrm{ET}-1$ binding parameters (data not shown). Therefore, the upregulation of $\mathrm{ET}_{\mathrm{A}}$ expressed on AOSMC was specific for $\mathbb{I L}-1 \beta$ among the cytokines tested.

Unaltered $\left[\mathrm{Ca}^{2+}\right]_{i}$ responses in $\mathrm{IL}-1 \beta$-treated AOSMC. ET-1-induced $\left[\mathrm{Ca}^{2+}\right]_{i}$ responses in $\mathrm{IL}-1 \beta$-untreated and -treated $(0.2 \mathrm{ng} / \mathrm{ml}$ for $8 \mathrm{~h})$ cells were indistinguishable from each other. Upon the addition of $10 \mathrm{nM}$ ET-1, $\left[\mathrm{Ca}^{2+}\right]$ increased immediately from the basal level $(89.6 \pm 3.9$ and $87.0 \pm 1.2 \mathrm{nM}$, in IL- $\beta$-untreated and -treated cells, respectively, means \pm SEM, $n=3)$ to a peak $(312.0 \pm 10.8$ and $317.0 \pm 9.3 \mathrm{nM})$ at about $30 \mathrm{~s}$, decreased rapidly to a sustained level $(126.0 \pm 3.4$ and $124.0 \pm 8.6 \mathrm{nM})$ by $1 \mathrm{~min}$, and maintained the sustained level for a further 10 min (Fig. $4 a$ ). The ET-1induced $\left[\mathrm{Ca}^{2+}\right]_{i}$ responses both in $\mathrm{IL}-1 \beta$-treated and -untreated cells were completely blocked by BQ123 $(3 \mu \mathrm{M})$, indicating that the $\left[\mathrm{Ca}^{2+}\right]_{\mathrm{i}}$ responses were mediated by $\mathrm{ET}_{\mathrm{A}}$ in both cases (Fig. $4 b$ ).

The upregulation of $\mathrm{ET}_{\mathrm{A}}$ and the unaltered $\left[\mathrm{Ca}^{2+}\right]_{\mathrm{i}}$ responses elicited by ET-1 suggested that the failure of ET-1 to induce MAPK activation in IL- $1 \beta$-treated cells was not due to an impairment of $\mathrm{PLC} / \mathrm{Ca}^{2+} /$ protein kinase $\mathrm{C}$ signaling pathway.

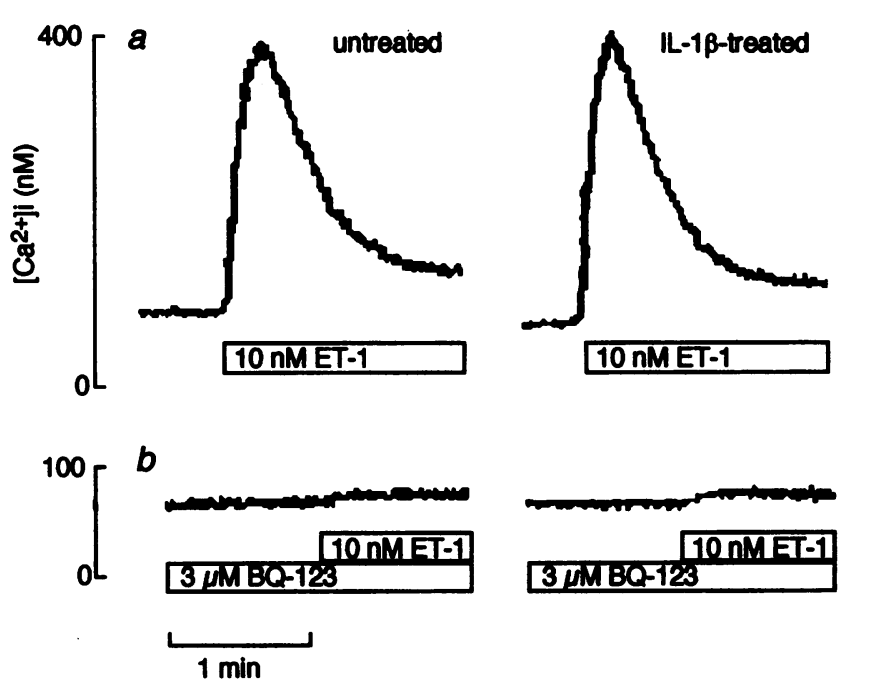

Figure 4. Lack of effects of $\mathrm{IL}-1 \beta$ treatment on ET-1-induced $\left[\mathrm{Ca}^{2+}\right]_{i}$ response in AOSMC. (a) Typical $\left[\mathrm{Ca}^{2+}\right]_{\mathrm{i}}$ responses induced by ET-1 $(10 \mathrm{nM})$ in cells cultured in the absence (left) or presence (right) of IL-1 $\beta(0.2 \mathrm{ng} / \mathrm{ml})$ for $8 \mathrm{~h}$. The cells were loaded with Fura-2, and $\left[\mathrm{Ca}^{2+}\right]_{\mathrm{i}}$ measurements were carried out as described in Methods. (b) Antagonistic effect of BQ123 on ET-1-induced $\left[\mathrm{Ca}^{2+}\right]_{\mathrm{i}}$ responses. 3 $\mu \mathrm{M}$ of BQ123 was added 1 min before stimulation with ET-1. Identical responses were observed for each condition in three separate experiments.

ET-1 stimulated cAMP formation in IL-1 $\beta$-treated $A O S M C$. It has been reported that, in some cell types, treatment of the cells with IL-1 resulted in an increased expression of phospholipase $\mathrm{A}_{2}\left(\mathrm{PLA}_{2}\right)(28-30)$, which is a rate-limiting enzyme in prostanoids metabolism. An increased production of prostaglandins, via acting in an autocrine/paracrine fashion, might affect the intracellular level of cAMP which works as a negative modulator of MAPK activation cascade (31-33). Therefore, we tested the hypothesis that the failure of ET-1 to induce MAPK activation in IL-1 $\beta$-treated AOSMC was due to a concomitant increase in cAMP formation secondary to activated prostanoids metabolism.

ET-1 did not stimulate CAMP formation in IL- $\beta$-untreated AOSMC, whereas a $\beta$-adrenergic receptor agonist Iso significantly increased the cAMP content (Fig. $5 a$ ). When the cells were treated with IL-1 $\beta(0.2 \mathrm{ng} / \mathrm{ml})$ for $4 \mathrm{~h}$, however, ET-1 caused a significant increase in cAMP formation. Peak level of ET-1-induced cAMP increase was obtained within 4-8 h of IL- $1 \beta$ treatment, and the ability of ET- 1 to stimulate cAMP formation declined gradually and disappeared after $24 \mathrm{~h}$ of treatment (Fig. $5 a$ ). The effect of ET-1 on IL- $1 \beta$-treated cells $(0.2 \mathrm{ng} / \mathrm{ml}$ for $8 \mathrm{~h})$ was dose dependent with $\mathrm{EC}_{50}$ values of $\sim 300 \mathrm{pM}$ and the maximum effects of three- to fourfold increase above the basal levels (Fig. $5 b$ ). IL-1 $\beta$ treatment caused no significant changes either in basal or Iso-stimulated cAMP formations. The ET-1-induced cAMP increase was not observed in cells incubated for $8 \mathrm{~h}$ with IL-8 $(10 \mathrm{ng} / \mathrm{ml})$, TNF $\alpha$ $(5 \mathrm{ng} / \mathrm{ml})$, or TGF $\beta(5 \mathrm{ng} / \mathrm{ml}$ ) (data not shown).

BQ123 completely suppressed the ET-1-induced cAMP increase in IL-1 $\beta$-treated AOSMC (Table III), indicating that the response was a consequence of $\mathrm{ET}_{\mathrm{A}}$ activation. The following observations, however, suggested that the response was not due to a direct coupling of $\mathrm{ET}_{\mathrm{A}}$ with $\mathrm{G} \alpha \mathrm{s}$, but due to autocrine/ 

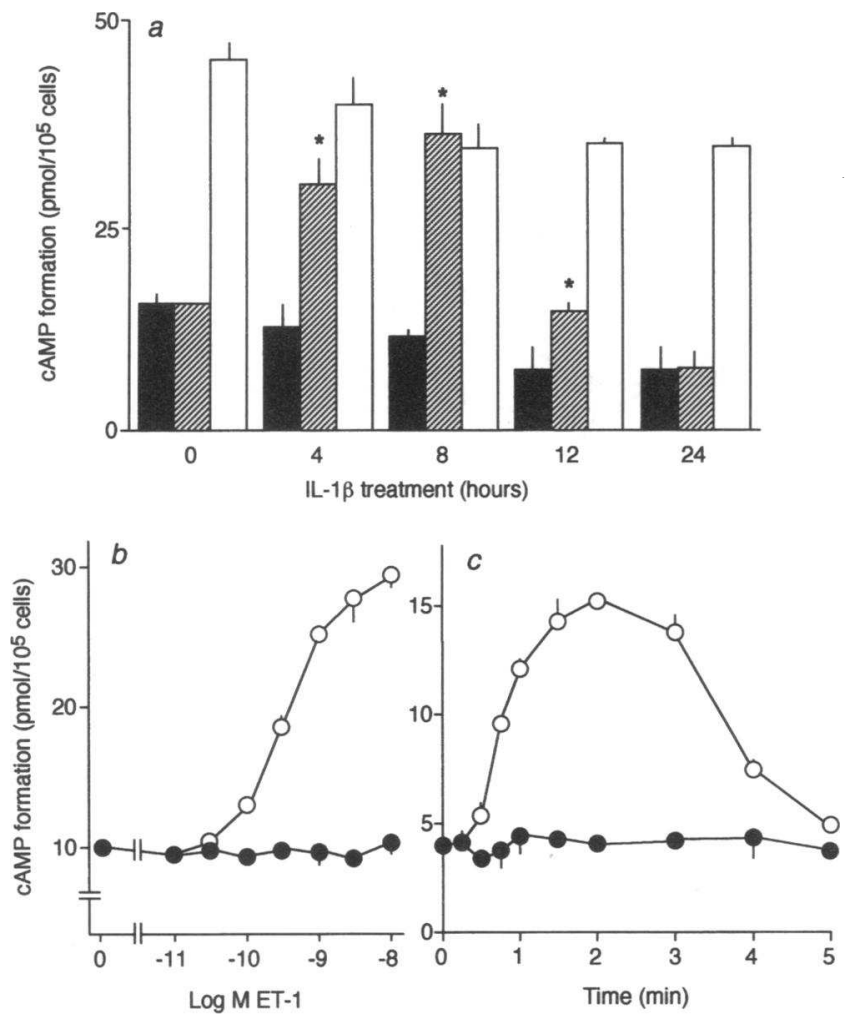

Figure 5. ET-1 stimulated cAMP formation in IL-1 $\beta$-treated AOSMC. (a) Dependency on the duration of IL- $\beta$ treatment. Cells in 24-well plates were treated with $\mathrm{IL}-1 \beta(0.2 \mathrm{ng} / \mathrm{ml})$ for $0,4,8,12$, and $24 \mathrm{~h}$, washed, incubated in HBS, and then stimulated with $10 \mathrm{nM}$ ET-1 (hatched bars) or $100 \mathrm{nM}$ Iso (white bars) for $3 \mathrm{~min}$ in the presence of $1 \mathrm{mM}$ IBMX. Black bars represent basal formations. (b) Dosedependency for the effect of ET-1. Cells treated (open circles) or untreated (filled circles) with IL- $1 \beta(0.2 \mathrm{ng} / \mathrm{ml}$ for $8 \mathrm{~h})$ were stimulated with increasing concentrations of ET-1 for $3 \mathrm{~min}$ in the absence of IBMX. (c) Kinetics of ET-1-induced cAMP increase. IL- $1 \beta$-treated (open circles) or -untreated (filled circles) cells were stimulated with $10 \mathrm{nM}$ ET-1 for up to $5 \mathrm{~min}$ in the absence of IBMX. In $a, b$, and $c$, the cAMP contents in the TCA-soluble cell extracts were determined by radioimmunoassay. Values shown are the means \pm SEM of three determinations each done in duplicate. $* P<0.05$, significantly different from the values of basal cAMP formations.

paracrine effects of prostanoids whose productions were stimulated by ET-1-induced increases in $\left[\mathrm{Ca}^{2+}\right]_{\mathrm{i}}$. First, a cyclooxygenase inhibitor, indomethacin, completely blocked the stimulatory effect of ET- 1 on cAMP formation in IL- $1 \beta$-treated cells (Table III). Second, a PLC inhibitor, U-73122, at $10 \mu \mathrm{M}$ (the concentration high enough to suppress ET-1 [10 nM]-induced $\left[\mathrm{Ca}^{2+}\right]_{\mathrm{i}}$ response in AOSMC; Ninomiya, H., unpublished observations), also blocked the effect of ET-1 (Table III). Neither indomethacin nor U-73122 inhibited Iso-induced cAMP formation. Third, not only ET-1 but other $\mathrm{Ca}^{2+}$-mobilizing agents such as angiotensin II or ionomycin stimulated cAMP formation in IL- $1 \beta$-treated cells (Table IV). Fourth, ET-1-induced $\left[\mathrm{Ca}^{2+}\right]_{\mathrm{i}}$ response and cAMP increase in the absence of IBMX took a very similar time course (Figs. $4 a$ and $5 c$ ). And fifth, ET- 1 -induced cAMP formation in $\mathrm{IL}-1 \beta$-treated cells depended on de novo protein synthesis during the treatment (Table V), which presumably was required for the increased expressions of enzymes involved in prostanoids metabolism.
Table III. ET-1-induced, but Not Iso-induced, cAMP Formation in IL-1 $\beta$-treated AOSMC Was Blocked by BQ123, Indomethacin, or $U-73122$

\begin{tabular}{lrcc}
\hline & \multicolumn{3}{c}{ cAMP formation (pmol/105 cells) } \\
\cline { 2 - 4 } & \multicolumn{1}{c}{ Basal } & ET-1 $(10 \mathrm{nM})$ & Iso $(100 \mathrm{nM})$ \\
\hline None & $10.5 \pm 1.0$ & $34.2 \pm 2.5$ & $36.5 \pm 3.1$ \\
BQ123 & $12.5 \pm 1.8$ & $13.4 \pm 2.3$ & $34.9 \pm 3.6$ \\
Indomethacin & $6.5 \pm 2.2$ & $7.5 \pm 0.6$ & $30.8 \pm 4.0$ \\
U-73122 & $8.5 \pm 3.1$ & $6.8 \pm 0.9$ & $32.3 \pm 1.2$
\end{tabular}

IL- $1 \beta$-treated $(0.2 \mathrm{ng} / \mathrm{ml}$ for $8 \mathrm{~h})$ cells were washed, incubated in HBS containing $1 \mathrm{mM}$ IBMX, and then stimulated for $3 \mathrm{~min}$ with ET-1 or Iso at the concentration indicated. BQ123 $(3 \mu \mathrm{M})$, indomethacin (10 $\mu \mathrm{M})$, or $\mathrm{U}-73122(10 \mu \mathrm{M})$ was added $10 \mathrm{~min}$ before stimulation. The contents of CAMP in the TCA-soluble cell extracts were determined by radioimmunoassay. Values are the means \pm SEM of three determinations each done in duplicate.

Indomethacin restored the ET-1-induced mitogenic responses of $I L-1 \beta$-treated AOSMC. According to the hypothesis that an increase in cAMP formation secondary to ET-1-induced prostanoids production impaired the mitogenic responses of IL$1 \beta$-treated cells, suppression of prostanoids metabolism should restore the responses. Indeed, when IL- $\beta$-treated cells were incubated with indomethacin $(10 \mu \mathrm{M})$ before stimulation, ET-1 caused significant increases both in MAPK activity at 3 min and in $\left[{ }^{3} \mathrm{H}\right]$ thymidine incorporation after $24 \mathrm{~h}$ (Fig. 6). The observed responses of IL- $1 \beta$-treated cells in the presence of indomethacin were compatible in degree with those of untreated, control cells. Indomethacin alone did not affect either MAPK activity or $\left[{ }^{3} \mathrm{H}\right]$ thymidine incorporation in IL- $\beta$ treated cells (Fig. 6). These results indicated that the molecular apparatus to transmit the mitogenic activities of ET-1 remained intact in IL- $\beta$-treated AOSMC and gave confirmatory evidence for the hypothesis described above.

\section{Discussion}

In the case of SMC, initial studies demonstrating mitogenic effects of ETs $(8-10)$ were followed by contradictory reports

Table IV. Not Only ET-1 but Other $\mathrm{Ca}^{2+}$-mobilizing Agents Stimulated cAMP Formation in IL-1 $\beta$-treated AOSMC

\begin{tabular}{llc}
\hline & \multicolumn{2}{c}{ cAMP formation $\left(\mathrm{pmol} / 10^{5}\right.$ cells) } \\
\cline { 2 - 3 } \multicolumn{1}{c}{ Stimulant } & Untreated & $\mathrm{IL}-1 \beta$-treated \\
\hline None & $10.5 \pm 0.3$ & $11.3 \pm 1.9$ \\
ET-1 $(10 \mathrm{nM})$ & $11.5 \pm 1.6$ & $43.1 \pm 4.2$ \\
Angiotensin $\mathrm{II}(100 \mathrm{nM})$ & $11.0 \pm 2.1$ & $19.4 \pm 2.5$ \\
Ionomycin $(1 \mu \mathrm{M})$ & $12.3 \pm 2.0$ & $48.0 \pm 4.9$ \\
\hline
\end{tabular}

IL- $1 \beta$-treated $(0.2 \mathrm{ng} / \mathrm{ml}$ for $8 \mathrm{~h})$ or -untreated cells were washed, incubated in HBS containing $1 \mathrm{mM}$ IBMX, and then stimulated for 3 min with each drug at the concentration indicated. The contents of cAMP in the TCA-soluble cell extracts were determined by radioimmunoassay. Values are the means \pm SEM of three determinations each done in duplicate. 
Table V. ET-1-induced cAMP Formation in IL-1 $\beta$-treated AOSMC Depended on De Novo Protein Synthesis during the Treatment

\begin{tabular}{crcr}
\hline & \multicolumn{3}{c}{ cAMP formation (pmol/10 cells) } \\
\cline { 2 - 4 } Cycloheximide & \multicolumn{1}{c}{ Basal } & ET-1 $(10 \mathrm{nM})$ & Iso $(100 \mathrm{nM})$ \\
\hline- & $10.6 \pm 1.8$ & $49.4 \pm 1.2$ & $45.3 \pm 1.8$ \\
+ & $8.5 \pm 2.4$ & $11.2 \pm 2.4$ & $52.9 \pm 0.6$
\end{tabular}

Starved cells in 24-well plates were treated with IL-1 $\beta(0.2 \mathrm{ng} / \mathrm{ml})$ for $8 \mathrm{~h}$ in the presence or absence of cycloheximide $(10 \mu \mathrm{g} / \mathrm{ml})$. They were washed, incubated in HBS containing $1 \mathrm{mM}$ IBMX, and then stimulated for 3 min with ET-1 or Iso. The contents of cAMP in the TCA-soluble cell extracts were determined by radioimmunoassay. Values are the means \pm SEM of three determinations each done in duplicate.

demonstrating a negative effect of ET-1 on DNA synthesis or proliferation $(17,34,35)$. There were also studies showing the need for the presence of other growth-promoting factors such as insulin (36) or PDGF (37) for ET-1 to show any mitogenic activities on SMC or the need for continual application of ET-1 to induce cell proliferation (38). Although these conflicting findings may simply reflect differences between the types of cells and the various experimental protocols used in each laboratory, the precise reason(s) for the discrepancies is unknown. In this study, we showed that, when applied to quiescent AOSMC, ET-1 alone, without any other growth-promoting agent, could induce MAPK activation, DNA synthesis, and cell proliferation. The observed effect of ET-1 on the cell proliferation, which is the end-point result of mitogenic activities, was as potent as about half of that of 5\% FCS (Fig. 1). These results firmly confirmed the mitogenic activities of ET-1 on AOSMC. We also demonstrated that, when cells were treated with IL$1 \beta$, a concomitant increase in cAMP formation secondary to ET-1-induced prostanoids production dramatically changed the mitogenic responses of the cells. Because in some types of SMC ET-1 has been reported to stimulate cAMP formation without any drug treatment (39), one of the reasons for the conflicting results obtained in the previous studies could be the differences of the effects of ET-1 on cAMP formation between types (and states) of the cells.

cAMP-increasing agents such as adenosine or prostaglandin $E$ have been known to counteract the mitogenic actions of various growth factors on SMC $(40,41)$, and accumulating evidence suggested that cAMP/cAMP-dependent kinase signaling inhibits the upstream of MAPKs in the signal transduction pathways activated by growth factor receptors. cAMP-increasing agents such as IBMX, forskolin, or prostaglandin $\mathrm{E}$ have been shown to inhibit Ras-dependent activation of Raf-1, B-raf, or MAPK kinase kinase stimulated by EGF, nerve growth factor, or a phorbol ester (31-33). The failure of ET-1 to induce MAPK activation in IL- $1 \beta$-treated AOSMC (Fig. 2) with a concomitant increase in cAMP formation (Fig. 5) is in accordance with these previous findings. Because the increase in cAMP formation in IL- $1 \beta$-treated AOSMC was apparently secondary to prostanoids production stimulated by an ET-1-induced increase in $\left[\mathrm{Ca}^{2+}\right]_{\mathrm{i}}$ (Tables III and IV), these results indicated that the sensitivity of the prostanoids metabolism to $\left[\mathrm{Ca}^{2+}\right]_{\mathrm{i}}$ could be one of the major factors to regulate the respon-
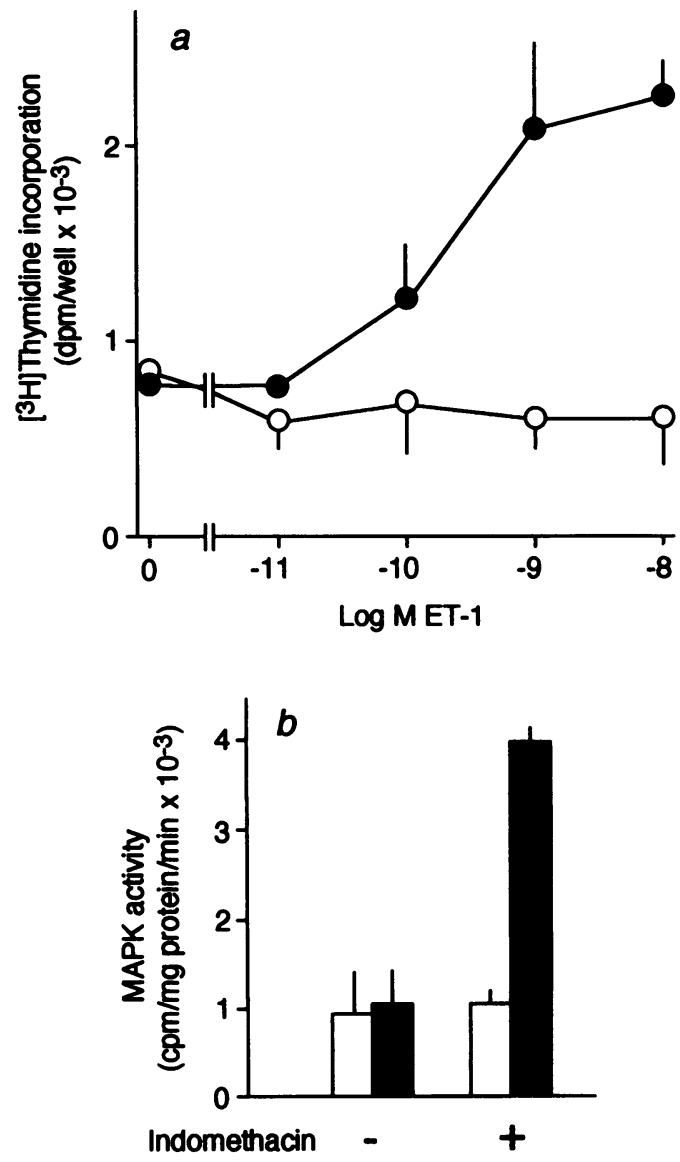

Figure 6. Indomethacin restored the mitogenic activities of ET-1 on IL$1 \beta$-treated AOSMC. (a) $\left[{ }^{3} \mathrm{H}\right]$ Thymidine incorporation. Starved cells in 96-well plates were treated with $\mathrm{IL}-1 \beta(0.2 \mathrm{ng} / \mathrm{ml})$ for $8 \mathrm{~h}$, washed, and then incubated in fresh serum-free medium. After preincubation for 10 min with (filled circles) or without (open circles) indomethacin (10 $\mu \mathrm{M}$ ), they were stimulated for $24 \mathrm{~h}$ with increasing concentrations of ET-1. During the last $4 \mathrm{~h}$ of the incubation, the cells were exposed to $\left[{ }^{3} \mathrm{H}\right]$ thymidine, and the radioactivity incorporated into the TCA-insoluble fraction was determined as described in Methods. Shown are the means \pm SEM of three determinations each done in triplicate. (b) MAPK activation. Starved cells in 6-well plates were treated with IL-1 $\beta(0.2$ $\mathrm{ng} / \mathrm{ml}$ ) for $8 \mathrm{~h}$, washed, and then incubated in serum-free medium supplemented with $5 \mathrm{mM}$ Hepes ( $\mathrm{pH} 7.4$ ). After preincubation for 10 min with or without indomethacin $(10 \mu \mathrm{M})$, they were either unstimulated (white bars) or stimulated (black bars) with $10 \mathrm{nM} \mathrm{ET-1}$ for 3 min. The MAPK activity in the cell lysate was measured using an assay kit (Amersham International). Shown are the means \pm SEM of three determinations each done in duplicate.

siveness of MAPK cascade to $\mathrm{Ca}^{2+}$-mobilizing mitogens such as ET-1.

The increased sensitivity of the prostanoids metabolism to $\left[\mathrm{Ca}^{2+}\right]_{\mathrm{i}}$ was caused by treatment of the cells with $\mathrm{IL}-1 \beta$, but not with other cytokines tested. Previous studies have shown that, in several cell types, IL-1 induces expression of key enzymes in the prostanoids metabolism such as cyclooxygenase or $\mathrm{CPLA}_{2}(28-30)$. Thus, one possible explanation for the increased sensitivity is the increased expression of the rate-limiting enzyme, cPLA . The activity of cPLA $_{2}$, however, is regulated both by $\left[\mathrm{Ca}^{2+}\right]_{i}$ and phosphorylation of the enzyme by MAPK (42-44), and the overexpression of enzyme in itself 
does not necessarily result in an enhanced production of prostanoids $(45,46)$. If we assume that the ET-1-induced activation of prostanoids metabolism in IL- $1 \beta$-treated AOSMC was due to the activation of $\mathrm{cPLA}_{2}$, the activation was apparently triggered by an increase in $\left[\mathrm{Ca}^{2+}\right]_{\mathrm{i}}$ but not by MAPK activation. Direct analyses on the expression level and activity of PLA are required to see whether the presumed activation of $\mathrm{CPLA}_{2}$ without MAPK activation was simply due to the overexpression of the enzyme or due to any other regulation mechanisms involved.

In addition to the induction of enzymes involved in prostanoids metabolism, IL- $1 \beta$ has been reported to stimulate proliferation of SMC via induction of PDGF-A-chain gene (47). In this study, however, IL- $1 \beta$ treatment in itself caused no changes in the rates of cell proliferation, $\left[{ }^{3} \mathrm{H}\right]$ thymidine incorporation, or in MAPK activity. PDGF-AA did not cause any increases in cell proliferation or in $\left[{ }^{3} \mathrm{H}\right]$ thymidine incorporation in our cell preparations (data not shown). Whether these discrepancies are simply due to the cell type used is not known.

An unexpected finding was that, in AOSMC, IL-1 $\beta$ induced upregulation of $\mathrm{ET}_{\mathrm{A}}$ (Fig. 3). This increase was not accompanied by any enhancement of the ET-1-induced signaling (Fig. 4 ), and its significance on the ET-1-induced cell responses remains unknown. As for the molecular mechanism of the upregulation, a preliminary study with Northern blotting analysis using human $\mathrm{ET}_{\mathrm{A}} \mathrm{CDNA}$ as a probe failed to reveal any significant changes in the expressions of $\mathrm{ET}_{\mathrm{A}}$ mRNA caused by IL- $1 \beta$ treatment (data not shown), suggesting an influence of IL- $1 \beta$ on the translational control or on the stability of the receptor protein.

Regardless of the molecular mechanisms involved, the findings described in this study gave a new insight into the possible role of ETs under inflammatory conditions during atherogenesis. IL- $1 \beta$ is a major cytokine released from activated macrophages which accumulate in the atherotic lesions and acts as a multipotent inflammatory mediator $(16,47)$. Various lines of evidence suggested that the conditions predisposed to atherogenesis or factors involved in it caused elevated plasma or tissue levels of ETs (11-15). If we assume that SMC which accumulate at the atherotic lesions are exposed to IL- $1 \beta$ and lose their responsiveness to the mitogenic activities of ETs like cultured AOSMC as observed here, ETs may not work as a mitogen on SMC under the inflammatory conditions but as a negative modulator of the cell proliferation. Thus the increase in the plasma or tissue levels of ETs may be one of the negative feedback phenomena to decelerate atherogenesis. We have shown recently that, in isolated cardiomyocytes from guinea pig, ET-1 exerted inhibitory effect on cAMP formation to counteract $\beta$-adrenergic receptor stimulation and suggested a hitherto unexpected role of ETs as a rescue to the damaged cells by counteracting the actions of arrythminogenic agents $(48,49)$. This study suggested the possibility of a similar, beneficial role of ETs in the pathological condition, atherogenesis. Clearly, there is a need for detailed analyses of the actions of ETs under various pathological conditions to verify the therapeutic values of ET receptor antagonists.

\section{Acknowledgments}

We are extremely grateful to Dr. A. F. James for invaluable discussions and to Miss Y. Katume for excellent technical assistance.

\section{References}

1. Inoue, A., M. Yanagisawa, S. Kimura, Y. Kasuya, T. Miyauchi, K. Goto, and T. Masaki. 1989. The human endothelin family: three structurally and pharmacologically distinct isopeptides predicted by three separate genes. Proc. Natl. Acad. Sci. USA. 86:2863-2867.

2. Yanagisawa, M., H. Kurihara, S. Kimura, Y. Tomobe, M. Kobayashi, Y. Mitui, Y. Yazaki, K. Goto, and T. Masaki. 1988. A novel potent vasoconstrictor peptide produced by vascular endothelial cells. Nature (Lond.). 332:411-415.

3. Arai, H., S. Hori, I. Aramori, H. Ohkubo, and S. Nakanishi. 1990. Cloning and expression of a cDNA encoding an endothelin receptor. Nature (Lond.). 348:730-732.

4. Hosoda, K., K. Nakao, H. Arai, S. Suga, Y. Ogawa, M. Mukoyama, G. Shirakami, Y. Saito, S. Nakanishi, and H. Imura. 1991. Cloning and expression of human endothelin-1 receptor cDNA. FEBS (Fed. Eur. Biochem. Soc.) Lett. 287:23-26.

5. Sakurai, T., M. Yanagisawa, Y. Takuwa, H. Miyazaki, S. Kimura, K. Goto, and T. Masaki. 1990. Cloning of a cDNA encoding a non-isopeptide-selective subtype of the endothelin receptor. Nature (Lond.). 348:732-735.

6. Fujitani, Y., K. Oda, M. Takimoto, T. Inui, T. Okada, and Y. Urade. 1992. Autocrine receptors for endothelins in the primary culture of endothelial cells of human umbilical vein. FEBS (Fed. Eur. Biochem. Soc.) Lett. 298:79-83.

7. Fujitani, Y., Y. Ueda, T. Okada, and H. Karaki. 1993. A selective agonist of endothelin type B receptor, IRL 1620, stimulates cyclic GMP increase via nitric oxide formation in rat aorta. J. Pharmacol. Exp. Ther. 267:683-689.

8. Dubin, D., R. E. Pratt, J. P. Cooke, and V. J. Dzau. 1989. Endothelin, a potent vasoconstrictor, is a vascular smooth muscle mitogen. J. Vasc. Med. Biol. 1:150-154.

9. Hirata, Y., Y. Takagi, Y. Fukuda, and F. Marumo. 1989. Endothelin is a potent mitogen for rat vascular smooth muscle cells. Atherosclerosis. 78:225228.

10. Bobik, A., A. Gooms, J. A. Millar, A. Mitchell, and S. Grinpulkel. 1990. Growth factor activity of endothelin on vascular smooth muscle. Am. J. Physiol. 258:C408-C415.

11. Lerman, A., B. S. Edwards, J. W. Hallett, D. M. Heublein, S. M. Sondberg, and J. C. Burnett. 1991. Circulating and tissue ir-ET in advanced atherosclerosis. N. Engl. J. Med. 325:997-1001.

12. Arendt, R. M., U. W. Lampen, L. Heucke, K. Suhler, M. Ritter, and W. O. Richter. 1989. Ir-ET circulates in human plasma: elevated concentrations in patients with hyperlipoproteinemia. Am. J. Hypertens. 3:336-342.

13. Miyauchi, T., Y. Sugishita, M. Matsuda, H. Sakai, T. Masaki, and K. Goto. 1992. Increased plasma concentration of endothelin-1 in cholesterol-fed rats. Atherosclerosis. 93:257-259.

14. Martin-Nizard, F., H. S. Houssaini, S. Lestavel-Delattre, P. Duriez, and J.-C.Furchart. 1991. Modified low density lipoproteins activate human macrophages to secrete immunoreactive endothelin. FEBS (Fed. Eur. Biochem. Soc.) Lett. 293:127-130.

15. Boulanger, C. M., F. C. Tanner, M. L. Bea, A. W. Hahn, A. Werner, and T. F. Luscher. 1992. Oxidized low density lipoprotein induces mRNA expression and release of ET from human and porcine endothelium. Circ. Res. 70:11911197.

16. Ross, R. 1993. The pathogenesis of atherosclerosis: a perspective for the 1990s. Nature (Lond.). 362:801-809.

17. Koide, M., Y. Kawahara, T. Tsuda, Y. Ishida, K. Shii, and M. Yokoyama. 1992. Endothelin-1 stimulates tyrosine phosphorylation and the activities of two mitogen-activated protein kinases in cultured smooth muscle cells. J. Hypertens. 10:1173-1182.

18. Grynkiewics, G. M., M. Poenie, and R. Y. Tsien. 1985. A new generation of $\mathrm{Ca}^{2+}$ indicators with greatly improved fluorescence properties. J. Biol. Chem. 260:3440-3450.

19. Ihara, M., K. Noguchi, T. Saeki, T. Fukuroda, S. Tsuchida, S. Kimura, T Fukami, K. Ishikawa, M. Nishikibe, and M. Yano. 1992. Biological profiles of highly potent novel endothelin antagonists selective for the $\mathrm{ET}_{\mathrm{A}}$ receptor. Life Sci. 50:247-255.

20. Ishikawa, K., M. Ihara, K. Noguchi, N. Mase, T. Saeki, T. Fukuroda, T. Fukami, S. Ozaki, T. Nagase, M. Nishikibe, and M. Yano. 1994. Biochemical and pharmacological profile of a potent and selective endothelin B-receptor antagonist, BQ-788. Proc. Natl. Acad. Sci. USA. 91:4892-4896.

21. Cowley, S., H. Paterson, P. Kemp, and C. J. Marshall. 1994. Activation of MAP kinase kinase is necessary and sufficient for PC12 differentiation and for transformation of NIH3T3 cells. Cell. 77:841-852.

22. Monsour, S. J., W. T. Matten, A. S. Hermann, J. M. Candia, S. Rong, K Fukasawa, G. F. V. Woude, and N. G. Ahn. 1994. Transformation of mammalian cells by constitutively active MAP kinase kinase. Science (Wash. DC). 265:966970.

23. Sun, H., N. K. Tonks, and D. Bar-Sagi. 1994. Inhibition of Ras-induced DNA synthesis by expression of the phosphatase MKP-1. Science (Wash. DC). 266:285-288.

24. Takuwa, Y., Y. Kasuya, N. Takuwa, M. Kudo, M. Yanagisawa, K. Goto, 
T. Masaki, and K. Yamashita. 1990. Endothelin receptor is coupled to phospholipase $\mathrm{C}$ via a pertussis toxin-insensitive guanine nucleotide-binding regulatory protein in vascular smooth muscle cells. J. Clin. Invest. 85:653-658.

25. Lange-Carter, C. A., C. M. Pleiman, A. M. Gardner, K. J. Blumer, and G. L. Johnson. 1993. A divergence in the MAP kinase regulatory network defined by MEK kinase and raf. Science (Wash. DC). 260:315-319.

26. Crespo, P., N. Xu, W. F. Simonds, and J. S. Gutkind. 1994. Ras-dependent activation of MAP kinase pathway mediated by G-protein $\beta \gamma$ subunits. Nature (Lond.). 369:418-421.

27. Kolch, W., G. Heidecker, G. Kochs, R. Hummel, H. Vahidi, H. Mischak, G. Finkenzeller, D. Marmé, and U. R. Rapp. 1993. Protein kinase C $\alpha$ activates RAF-1 by direct phosphorylation. Nature (Lond.). 364:249-252.

28. Kerr, J. S., T. M. Stevens, G. L. Davis, J. A. MacLaughlin, and R. R. Harris. 1989. Effects of recombinant interleukin- $1 \beta$ on phospholipase $A_{2}$ activity, phospholipase $A_{2}$ mRNA level, and eicosanoid formation in rabbit chondrocytes. Biochem. Biophys. Res. Commun. 165:1079-1084.

29. Pfeilschifter, J., J. Leighton, W. Pignat, F. Marki, and K. Vosbeck. 1991. Cyclic AMP mimics, but not mediates, interleukin-1- and tumor-necrosis-factorstimulated phospholipase $A_{2}$ secretion from rat renal mesangial cells. Biochem. J. 273:199-204.

30. Lin, L.-L., A. Y. Lin, and D. L. DeWitt. 1992. Interleukin $-1 \alpha$ induces the accumulation of cytosolic phospholipase $A_{2}$ and the release of prostaglandin $\mathrm{E}_{2}$ in human fibroblasts. J. Biol. Chem. 267:23451-23454.

31. Cook, S. J., and F. McCormick. 1993. Inhibition by cAMP of ras-dependent activation of raf. Science (Wash. DC). 262:1069-1072.

32. Wu, J., P. Dent, T. Jelinek, A. Wolfman, M. J. Weber, and T. W. Sturgill. 1993. Inhibition of the EGF-activated MAP kinase signaling pathway by adenosine 3',5'-monophosphate. Science (Wash. DC). 262:1065-1069.

33. Lange-Carter, C. A., and G. L. Johnson. 1994. Ras-dependent growth factor regulation of MEK kinase in PC12 cells. Science (Wash. DC). 265:14581461.

34. Scott-Burden, T., T. J. Resink, A. W. A. Hahn, and P. M. Vanhoutte. 1991. Induction of endothelin secretion by angiotensin II: effects on growth and synthetic activity of vascular smooth muscle cells. J. Cardiovasc. Pharmacol. 17:S96-S100.

35. Chua, B. H. L., C. J. Krebs, C. C. Chua, and C. A. Diglio. 1992. Endothelin stimulates protein synthesis in smooth muscle cells. Am. J. Physiol. 262:E412E416.

36. Komuro, I., H. Kurihara, T. Sugiyama, F. Takuwa, and Y. Yazaki. 1988. Endothelin stimulates c-fos and c-myc expression and proliferation of vascular smooth muscle cells. FEBS (Fed. Eur. Biochem. Soc.) Lett. 238:249-252.
37. Weissberg, P. L., C. Witchell, A. P. Davenport, T. R. Hesketh, and J. C. Metcalfe. 1990. The endothelin peptides ET-1, ET-2, ET-3 and sarafotoxin S6B are co-mitogenic with platelet-derived growth factor for vascular smooth muscle cells. Atherosclerosis. 85:257-262.

38. Alberts, G. F., K. A. Peifley, A. Johns, J. F. Kleha, and J. A. Winkles. 1994. Constitutive endothelin-1 overexpression promotes smooth muscle cell proliferation via an external autocrine loop. J. Biol. Chem. 269:10112-10118.

39. Eguchi, S., Y. Hirata, T. Imai, and F. Marumo. 1993. Endothelin receptor subtypes are coupled to adenylate cyclase via different guanyl nucleotide-binding proteins in vasculature. Endocrinology. 132:524-529.

40. Nilsson, J., and A. G. Olsson. 1984. Prostaglandin $E_{1}$ inhibits DNA synthesis in arterial smooth muscle cells stimulated with platelet-derived growth factors. Atherosclerosis. 53:77-82.

41. Jonzon, B., J. Nilsson, and B. B. Fredholm. 1985. Adenosine receptormediated changes in cyclic AMP production and DNA synthesis in cultured arterial smooth muscle cells. J. Cell. Physiol. 124:451-456.

42. Clark, J. D., L.-L. Lin, R. W. Kritz., C. C. Ramesha, L. A. Sultzman, A. Y. Lin, N. Milona, and J. L. Knopf. 1991. A novel arachidonic acid-selective cPLA $_{2}$ contains a $\mathrm{Ca}^{2+}$-dependent translocation domain with homology to PKC and GAP. Cell. 65:1043-1051.

43. Nemenoff, R. A., S. Winitz, N.-X. Qian, V. V. Putten, G. L. Johnson, and L. E. Heasley. 1993. Phosphorylation and activation of a high molecular weight form of phospholipase $A_{2}$ by $\mathrm{p} 42$ microtubule-associated protein 2 kinase and protein kinase C. J. Biol. Chem. 268:1960-1964.

44. Lin, L.-L., M. Wartmann, A. Y. Lin, J. L. Knopf, A. Seth, and R. J. Davis. 1993. cPLA ${ }_{2}$ is phosphorylated and activated by MAP kinase. Cell. 72:269-278.

45. Pernas, P., J. Masaliah, J.-L. Olivier, C. Salvat, T. Rybkine, and G. Bereziat. 1991. Type II phospholipase $A_{2}$ recombinant overexpression enhances stimulated arachidonic acid release. Biochem. Biophys. Res. Commun. 178:1298-1305.

46. Lin, L.-L., A. Y. Lin, and J. L. Knopf. 1992. Cytosolic phospholipase $\mathbf{A}_{2}$ is coupled to hormonally regulated release of arachidonic acid. Proc. Natl. Acad. Sci. USA. 89:6147-6151.

47. Raines, E. W., S. K. Dower, and R. Ross. 1989. Interleukin-1 mitogenic activity for fibroblasts and smooth muscle cells is due to PDGF-AA. Science (Wash. DC). 243:393-396.

48. James, A. F., L.-H. Xie, Y. Fujitani, S. Hayashi, and M. Horie. 1994. Inhibition of the cardiac protein kinase A-dependent chloride conductance by endothelin-1. Nature (Lond.). 370:297-300.

49. Ono, K., G. Tsujimoto, A. Sakamoto, K. Eto, T. Masaki, Y. Ozaki, and M. Satake. 1994. Endothelin-A receptor mediates cardiac inhibition by regulating calcium and potassium currents. Nature (Lond.). 370:301-304. 